4 Wilson R, Kanto W P, Jr, McCarthy B J, et al. Age at onset of necrotizing enterocolitis. an epidemiologic analysis. Pediatr Res 1982; 16: 82-4.

5 Kliegman R M, Fanaroff A A. Neonatal necrotising enterocolitis: a nine-year experience. I. Epidemiology and uncommon observations. Am J Dis Child 1981; 135: 603-7.

F EYAL

Paediatric Department, Hadassah University Hospital, Mount Scopus, POB 24035, :1-91240 Jerusalem, Israel

\section{Systemic candidiasis}

Sir,

Systemic candidiasis occurs particularly at the extremes of life and in the immuno-compromised host. Unfortunately the drugs currently available often have side effects that limit their use and most must be administered by the intravenous route necessitating admission to hospital. Ketoconazole is an imidazole derivative with a wide spectrum of action against pathogenic fungi. It is effective if taken orally in the treatment of chronic mucocutaneous candidiasis. ${ }^{1}$ We have recently used oral ketoconazole in the treatment of systemic candidiasis in a neonate.

After premature onset of labour a $650-\mathrm{g}$ boy was delivered by caesarean section at 28 weeks' gestation. He developed hyaline membrane disease and required intermittent positive pressure ventilation from birth until day 11. On day 21 he developed symptoms and signs of necrotising enterocolitis. Oral feeds were stopped and a 10-day course of antibiotics (ampicillin, metronidazole, gentamicin) was given. No organisms were isolated on any cultures. Normal feeds were reintroduced without any problem 2 weeks later. Progress was then satisfactory until his 64th day when his condition deteriorated. After a septic screen, he was started on ceftazidime $(100 \mathrm{mg} / \mathrm{kg}$ a day). Two days later a left inguinal hernia was found which required surgical reduction after which his condition remained poor, his abdomen becoming distended with ascitic fluid. Culture of the ascitic fluid and his 64th day blood culture grew Candida albicans, sensitive to amphotericin B, flucytosine, miconazole, and ketoconazole. He was started on oral ketoconazole, $3.5 \mathrm{mg}$ once daily, equivalent to an adult dose of $200 \mathrm{mg}$ daily, tecause of his deteriorating condition and positive cultures. On this regimen there was a gradual improvement in his condition. There were no local or systemic side effects during treatment. Treatment was continued for a total of 10 weeks. Cultures once treatment was stopped were sterile. On day 119 he was discharged home weighing $2.52 \mathrm{~kg}$. He is now 6 months old and his progress has been satisfactory.

Studies indicate that ketoconazole is a safe drug with low toxicity. ${ }^{2}$ Reversible liver toxicity, manifested by mild acute hepatitis, has been reported. ${ }^{1}$ We did not experience this problem in our patient. Alternative forms of treatment of systemic candidiasis have a greater incidence of toxic side effects and must be given by the intravenous route. The use of amphotericin B is limited by its nephrotoxicity and flucytosine may cause bone marrow depression. Miconazole has been reported to cause superficial thrombophlebitis at the site of intravenous administration and ventricular tachycardia. ${ }^{3}$ Rarer cases of cardiorespiratory arrest have also been documented with its use. ${ }^{4}$

The response of our patient to ketoconazole indicates that it is an effective agent in the treatment of systemic candidiasis. It has the advantage of being well absorbed when given orally. Thus one is not faced with the problem of long-term intravenous therapy, a feature of particular importance in the neonate.

\section{References}

1 Petersen E A, Alling D W, Kirkpatrick C H. Treatment of chronic mucocutaneous candidiasis with ketoconazole. Ann Intern Med 1980; 93: 791-5.

2 Anonymous. Ketoconazole - an antifungal drug for oral use. Drug Ther Bull 1981; 19: 91-2.

3 Clarke M, Davies D P, Odds F, Mitchell C. Neonatal systemic candidiasis treated with miconazole. $\mathrm{Br}$ Med $\mathrm{J}$ $1980 ; 281: 354$.

4 Fainstein V, Bodey G P. Cardiorespiratory toxicity due to miconazole. Ann Intern Med 1980; 93: 432-3.

O J Hensey AND R W I COOKe Department of Child Health, Liverpool Maternity Hospital, Oxford Street, Liverpool $L 77 B N$

\section{Electronmicroscopy in 'absence' of islets of Langerhans in a newborn infant}

Sir,

In a previous report ${ }^{1}$ we described the case history and histology at necropsy of a boy with congenital diabetes mellitus who died on the third day of life. His brother had died 8 years previously after a remarkably similar neonatal illness, but with no diagnosis established. Our patient weighed only $2.13 \mathrm{~kg}$ at term, was obviously wasted, and developed respiratory distress, although the chest $x$-ray film was normal. Blood gas analysis indicated a mild metabolic acidosis which increased during the next 24 hours despite administration of sodium bicarbonate. The urine contained large amounts of glucose and acetone, and the blood sugar at 36 hours was $>22$ $\mathrm{mmol} / \mathrm{l}$. Despite intravenous fluids and insulin, he died suddenly from pulmonary haemorrhage at age 40 hours.

Studies at necropsy showed that the pancreas was externally normal but no recognisable islets of Langerhans could be found. There were a few lymphoid aggregates and occasional granular cells which might have been of endocrine origin, but these gave a negative staining reaction for $\alpha$ - and $\beta$-cells. Small amounts of insulin $(54 \mathrm{IU} / \mathrm{g})$ could be measured in the pancreatic tissue, and were probably derived from the insulin given before death (the concentration in the pancreas of 2 'control' infants exceeded $2000 \mathrm{IU} / \mathrm{g}$ in each case). Immunocytochemistry and electron microscopical examination, prompted by comments after the publication 

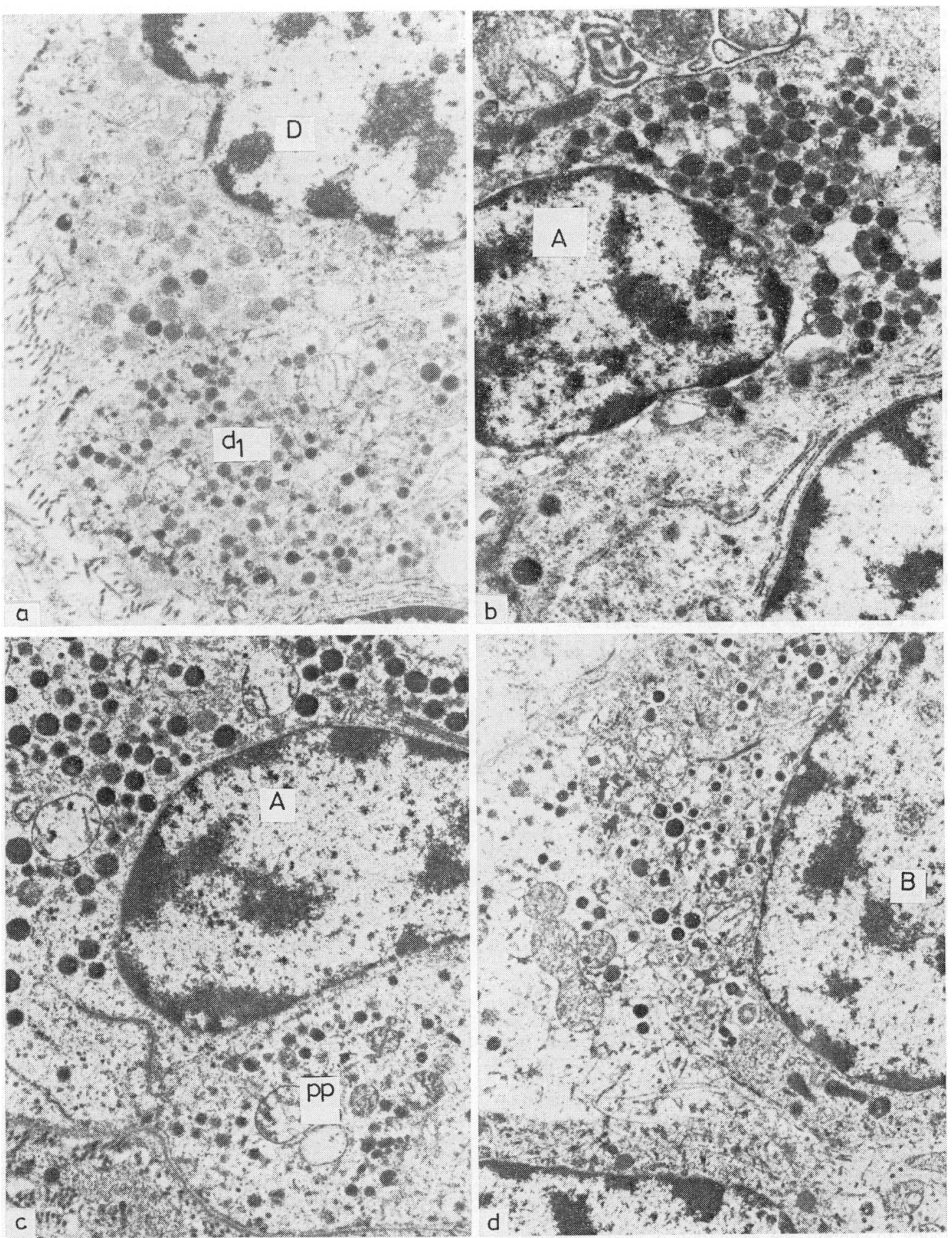

을

Figure Electron photomicrographs of endocrine cells from the pancreas $\times 13000$. (a) D cell (large granules) and $d_{1}$ cells with peptides stored in them as yet unidentified. (b) Solitary A cell (large dense granules) surrounded by acinar cells. (c) A cell and probable pp cell. (d) Typical B cell with $\beta$ - (insulin) granules in the dark cell. Granules of light cell may also be insulin but are not clearly identifiable. 
of the report, have now added new information to this previously undescribed condition.

Immunocytochemistry using either paraffin sections or cryostat sections of formalin-fixed tissue, and highly specific antibodies to insulin (dilution 1:9000), glucagon (dilution 1:5000), somatostatin (dilution 1:1000), and vasoactive intestinal polypeptide (dilution 1:1000) showed only very few, weakly stained somatostatin cells. Electron microscopical examination of pancreatic tissue which had been taken almost agonally and immediately fixed in $2.5 \%$ glutaraldehyde in $0.1 \mathrm{~mol} / 1$ phosphate buffer at $4^{\circ} \mathrm{C}$ confirmed that autolysis at necropsy was minimal. The exocrine, acinar cells appeared normal. Rare, often solitary endocrine cells could be identified by their typical granule structures. Most of them were the D-(somatostatin) cells (Figure (a) and $\alpha$-(glucagon) cells (b and c), although occasional pp cells (d) and cells with an unidentified polypeptide hormone (labelled $d$ in a) could also be seen. Only very rarely was a B-cell with insulin granules (Figure d) observed. None of these cells was associated, as in a normal pancreas, with large groups of 'islets'. Thus, all 4 well-recognised endocrine cell types were identified, although in extremely reduced numbers.

We have been unable to trace any previous or subsequent descriptions of similar infants with congenital absence of pancreatic $\beta$-cells.

\section{Reference \\ 1 Dodge J A, Laurence K M. Congenital absence of islets of Langerhans. Arch Dis Child 1977; 52: 411-3.}

\section{K M Laurence and J A Dodge Department of Child Health, G R NewMaN Department of Histopathology, Welsh National School of Medicine, Heath Park, Cardiff CF 4 XN Julia M POLAK Department of Histochemistry, Royal Postgraduate Medical School, Hammersmith Hospital, London W12 OHS}

\section{Plasma prostacyclin from birth to adolescence}

Sir,

The finding that plasma concentrations of 6-ketoprostaglandin $F_{1 \alpha}$ (6-keto-PGF $1 \alpha$ ), one of several degradation products of prostacyclin $\left(\mathrm{PGI}_{2}\right)$, fall from a high value at birth to a lower, steady range in the first week is of interest. ${ }^{1}$ Urinary excretion of 6-keto-PGF $1 \alpha$ shows a similar pattern ${ }^{2}$ and fetal plasma concentrations are markedly raised at mid-trimester declining towards term. ${ }^{3}$ However, it is presumptive to assume that these findings reflect physiological changes in plasma $\mathrm{PGI}_{2}$ in the fetus and newborn. Firstly there is no universal agreement that $\mathrm{PGI}_{2}$ acts as a circulating hormone. ${ }^{45}$ Furthermore, neonatal plasma demonstrates a diminished ability to support the generation of $\mathrm{PGI}_{2}$-like activity from endothelium in vitro, ${ }^{6}$ and there is an argument that the normal bleeding time of the neonate is the result of a balanced reduction of platelet pro-aggregatory and endothelial anti-aggregatory (possible $\mathbf{P G I}_{2}$ ) effect. In the fetus or newborn it is unacceptable to infer from the observations on 6-keto- PGF $_{1 \alpha}$ concentration that plasma $\mathbf{P G I}_{2}$ levels or vascular $\mathbf{P G I}_{2}$ effects are greater than at other ages without knowledge of the distribution, catabolism, and excretion of the measured metabolite. Unfortunately this information is lacking and a more cautious interpretation, such as that offered by other investigators, ${ }^{2}$ is appropriate.

\section{References}

1 Kaapä P, Viinikka L, Ylikorkala O. Plasma prostacyclin from birth to adolescence. Arch Dis Child 1982; 57: 459-61.

2 Scherer B, Fischer S, Siess W, Weber P C. Analysis of 6 keto prostaglandin $F_{1 \alpha}$ in human urine: age specific differences. Prostaglandins 1982; 23: 41-52.

${ }^{3}$ MacKenzie I Z, MacLean D A, Mitchell M D. Prostaglandins in the human fetal circulation in mid-trimester and term pregnancy. Prostaglandins 1980; 20: 649-54.

4 Haslam R J, McClenaghan M D. Measurement of circulating prostacyclin. Nature 1981 ; 292: 364-6.

5 Blair I A, Barrow S E, Waddell $K$ A, Lewis $P$ J, Dollery C T. Prostacyclin is not a circulating hormone in man. Prostaglandins 1982; 23: 579-89.

6 Stuart M J. Deficiency of plasma $\mathrm{PGI}_{2}$-like regenerating activity in neonatal plasma. Reversal by vitamin $\mathrm{E}$ in vitro. Pediatr Res 1981; 15: 971-3.

\section{M TAYLOKO \\ Department of Nephrology, The Children's Hospital, Ladywood Middleway, Ladywood, Birmingham B16 8ET \\ Department of Physiology, University of Birmingham, Medical School, Birmingham B15 2TT}

Dr Kääpa and co-workers comment:

We thank Dr Taylor and Dr Lote for their interest in our work. ${ }^{1}$ We agree that since submitting our paper it has been increasingly evident that the concentration of prostacyclin $\left(\mathrm{PGI}_{2}\right)$ in the circulation is lower than is needed to affect platelet aggregation in vitro. ${ }^{2-5}$ Thus the concentration of 6-keto-prostaglandin $F_{1 \alpha}$ (6-keto$\mathrm{PGF}_{1 \alpha}$ ), the main degradation product of $\mathrm{PGI}_{2}$ in human plasma, ${ }^{6}$ does not necessarily reflect the changes of PGI $_{2}$ in the circulation. Nevertheless, plasma and urinary 6-keto-PGF $1 \alpha$ could well reflect the physiologically important production of $\mathrm{PGI}_{2}$ in the body.

We believe that our main finding on the increased $\mathrm{PGI}_{2}$ production during the neonate period is valid. ${ }^{1}$ The fact that the urinary excretion of 6-keto- PGF $_{1 \alpha}$, as measured by radioimmunoassay ${ }^{7}$ and gas chromatography-mass spectrometry, ${ }^{8}$ is increased during the first days of life strongly supports our view and clearly shows that the increased plasma 6-keto-PGF ${ }_{1}{ }^{1}$ is not a result 